\title{
Multivariate Analysis for Determinants of Online Consumers Trust
}

\author{
Aprilia Aryanti Widyasari ${ }^{1}$ Putri Pratama Deliana Nursafitri ${ }^{1}$ Achmad Yanu Alifianto $^{1}$ \\ ${ }^{\text {I} M a n a g e m e n t ~ D e p a r t m e n t, ~ F a c u l t y ~ o f ~ E c o n o m y ~ a n d ~ B u s i n e s s, ~ U n i v e r s i t a s ~ D i n a m i k a, ~ I n d o n e s i a ~}$ \\ "Corresponding author. Email: achmadyanu@gmail.com
}

\begin{abstract}
This research aims to examine the effect of customer satisfaction on customer trust, the effect of security perception on customer satisfaction and customer trust, the influence of privacy on customer satisfaction and customer trust, the influence of brand awareness on customer satisfaction and customer trust, as well as the influence of customer satisfaction mediation on the relationship between perception security, privacy and brand awareness with customer trust. This research focuses observations on 100 people in Surabaya who have made transactions on online shopping sites. Private students and employees dominate the number of respondents in this research. To test the research hypothesis, this research adopted the Structural Equation Model-Partial Least Square (SEM-PLS) technique using SmartPLS. This research proves that brand awareness has a significant effect on customer trust and customer satisfaction, security perceptions have a significant effect on customer trust and customer satisfaction, privacy has a significant effect on customer trust and not on customer satisfaction, and customer satisfaction on customer trust.
\end{abstract}

Keywords: Security Perception, Privacy Perception, Brand Awareness, Satisfaction, Trust.

\section{INTRODUCTION}

Nowadays innovation is developing so fast. The development of this innovation is something that can simplify reciprocal communication for individuals. The web is not a stranger to the public. That is not because it is comfort and common sense, but with that the web is very accommodating in completing all things and tasks. The factor of rapid increase was due to the improved infrastructure and the ease of obtaining smartphones or handheld gadgets[1]. Many studies have stated that in the world of publicity and the use of the web is one of ecommerce practices. Providing companies or locations for exchanges and offices to offer goods and online administration directly toe-commerce[2].

There are several views which state that e-commerce is a modern concept that can be presented onthe World Wide Web as a method of buying or offering goods[3]. The web is designed to buy data through data systems and is prepared for bidding or trading[4]. Nowadays, very advanced there are various developments that have been made to attract customers[5]. The advertised item moves from item to product easily buying and offering[6]. Today buying and selling online is a form of innovation that is considered by the public to be a trend[7]. More progress and a faster pace ofinnovation[8].

One must really have a look at online shopping sites[9]. Many people use this opportunity to use it in various ways. Today many people are using the internet as a site to make money, where they buy and sell products online[10]. Customers believe that the main factor in buying an item. Most before these products, customers, manufacturers and companies have to buy the goods advertised to create customer certainty, so as to create customers who want to know and trust in the goods on display[11]. In the case that consumers trust online stores provided by companies, they can increase the desire to buy online[5].

Manystudies that prove the existence of trust seen from the calculations needed in the development process and 


\section{Procedia Business and Financial Technology}

Proceedings of the 2nd International Conference on Business and M anagement of T echnology (ICO N BM T 2020) - Part 2

maintain a good bond with the buyer[12]. Understanding reliability that fits the view that defines trust as someone who is confident in doing business with someone who is sharp and trustworthy[6]. There is an opinion which states that customer desires are perceived implementation or perceived benefits of an item compared to buyer desires where customer satisfaction causes brand dependence. When buyers are full ofbrand implementation, they buy the brand, use the brand, and continue to declare other brand preferences based on customer involvement in actually using theproduct.

Satisfaction with this shopper is one of the key figures that will determine your business victory. Some experts classify that achievement is a funny feeling or disappointment towards the person producing the product, because achievement compares the observed performance of the item with their desires[4]. Customer fulfillment is a post-purchase rating, where results fall below or even exceed customer expectations[5]. If you are not satisfied, you will feel dissatisfied but will not fulfill your wishes[11]. Some views state that the buyer's fulfillment plan is the convenience advertised by the manufacturer to the buyer.

These two variables along with fulfillment also include a positive impact on the certainty of online customers[12]. The linkages of the four aspects described in this question indicate by establishing security and protection of perception as a precursor factor, fulfillment as a mediator variable, and online buyers believe as an endogenous factor[6]. Security awareness is known as acceptance of security buyers in e-commerce exchanges[10]. Many experts classify security perceptions as the buyer's subjective belief that a traveling and able third party will not see, store or control personalinformation.

However, this raises hopes for certainty. Security is one of the main problems facing web clients. Violations on web media are unusual extensions and can vary in size for several reasons[7]. At the first point, the personal and corporate character in the web world is lightly made, but difficult to show by law[9]. At present, you do not need financial management resources that can be done properly on one of the web. The third point is that the web provides extensive facilities for customers who are accident victims.

Suggestions about this question are important for the administration and e-commerce analyst framework to consider protection discernment variables, trust discernment, opportunity discernment, convenience discernment, and ease of perception in carrying out and creating an e-commerce exchange framework[8].

Many studies show that brand awareness is the ability of consumers with the aim of planning and identifying whether a brand can be a component of certain groups of goods. The expansion of mindfulness is a mechanism for developing brand exhibits. Mindfulness also influences perception and behavior. In the event that abrand is in the customer's intelligence, then the brand will be considered $122 / 180$ to determine their acquisition options.

Despite the fact that it does not show all thebrands that have the best intelligence before the customer decides to buy a certain item before they will surely consider the knock of the intelligence brand. Highly loved by brand awareness itself has four levels to create value in the minds of potential customers. One party states four levels, the main brand (unaware brand) does not pay attention to the level that the customer does not pay attention to the presence of the brand in the showcase, and in their intelligence all brands are equal in quality and brand. This research is divided into several sections consisting of the introduction, literature review, development of research hypotheses, research methods, followed by results and discussion as well as drawing conclusions.

\section{LITERATURE REVIEW HYPOTHESIS DEVELOPMENT}

AND

\subsection{The Effect of Satisfaction on Trust}

Many people say that trust is built because of the desire of other consumers who act to approve the customer's needs and plans. Satisfaction is a result of assessing past knowledge exchanges. Satisfaction will occur if the client assesses the involvement of the exchange in a good way. With a positive impression and evaluation of the transaction before then the buyer becomes confident by transacting at the online store. Consumer satisfaction depends on the execution of goods that appear absolute to the desires of consumers. If the item's execution is in line with expectations, the consumer is fulfilled. If the execution exceeds the wishes, the client is very satisfied. Clients who are fulfilled not because they make them believe but moreover repeat purchases, they become clients who tell others about their great meeting with the item. From some of the definitions that have been explained, then there is a hypothetical formula that will be shown below:

\section{H1: There is a positive and significant effect on satisfaction with Trust.}

\subsection{The Effect of Security Perception on Trust}

Some say security is marked as a discernment of security spending in e-commerce exchanges. Trust is built because there is trust in other consumers who will act on the requirements and needs of the buyer. One expert proved that security recognition can be directly and expresslyrelated to trust. If customers with online dealers feel secure in their transactions, customers will almost certainly buy online. From this description, a hypotheses can be defined as: 


\section{Procedia Business and Financial Technology}

Proceedings of the 2nd International Conference on Business and M anagement of T echnology (ICO N BM T 2020) - Part 2

\section{H2: There is a positive and significant effect on Security} Perception with Trust.

\subsection{The Effect of Brand Awareness on Trust}

Some experts say brand awareness is the planned capacity of consumers with the aim of reviewing a brand that can be part of a group of goods. trust is built bythe belief that other parties are acting in accordance with the wishes of the customer. On expansion to fulfillment, brand awareness can also have a coordinating and positive effect on the certainty of online shoppers. Confidence in shoppers' online stores is everywhere in online shopping. Increasingly popular, the more convinced buyers believe in the quality of an impenetrable online store. Buyer's confidence in online stores lies in the popularity of online shopping. More and more prevalent, more and more buyers are trusting and trusting in the unshakable quality of online stores. From this explanation, it can be specified as follows:

\section{H3: There is a positive and significant effect on Brand} Awareness with Trust.

\subsection{The Effect of Security Perceptionon Satisfaction}

Privacy perception is characterized by the buyer's acknowledgment of security in carrying out an online store exchange. The customer is said to be satisfied if the affirmation of the quality of an item is in line with the wishes of the client. If the customer feels safe shopping online at that time, a shopper is satisfied. One expert said that it appears that there is a positive impact on fulfilling online security clients. From this description, the formula below can be classified:

\section{H4: There is a positive and significant effect of Security Perception on Satisfaction.}

\subsection{The Effect of Privacy Perceptionon Satisfaction}

The perception of privacy can make sense that online sellers collect and utilize information that is almost individually wrong. In this way the client is hesitant to enter their individual information when the location asks for the data. This is because the emphasis is on the collection and misuse of information sent via the web, and the data is used. The effect is that online customers may be reluctant to provide personal information or budgets to online merchants, because they can abuse personal information or disclose it to other parties. Client satisfaction is the level where the assertion of the quality of an item in accordance with the wishes of the client If the security of the buyer is maintained and ensured, the buyer feels satisfied to do shopping online. From this description, the formula can be classified as follows:

\section{H5: There is a positive and significant effect of Privacy Perception on Satisfaction.}

\subsection{The Effect of Brand Awareness on Satisfaction}

Some experts claim that customer satisfaction is the level at which the recognition of the quality of a product is in accordance with the wishes of the client. Brand awareness is the planned capacity of the buyer aimed at identification or confirmation that a brand is part of a particular product category. The buyer buys goods in a brand that they know now because he believes that the goods purchased are quality goods and are tried so that consumers are satisfied. From this explanation, the formula can be classifiedbelow:

\section{H6: There is a positive and significant effect of Brand Awareness on Satisfaction.}

\section{RESEARCH METHOD}

This study belongs to a quantitative study that uses selected methodological studies as an important data source. The test survey was carried out by certain residents and the survey was adopted as a driving data collection device. This research strategy, which is centered on collecting respondent data that contains specific information, allows the examiner to understand the problem. The causal question posed asks about observations that examine the causal linkages, especially the linkages to the effects of autonomous factors that favor the variable $Y$.

The methodology used may be an objective test Objective testing is a technique for conducting tests based on the idea of changing certain criteria to improve test accuracy. The test is a male or female client and meets the following criteria including (a) customers who have carried out trade exchanges through Social media on Instagram; and (b) when buying and selling carried out by respondents at least about the last 6 months. Based on the opinion of an expert the sample size used in this idea might be test metrics equivalent to 100-200. With this view, 20 questions were asked from respondents. This research focuses observations on 100 people in Surabaya who have made transactions on online shopping sites. Private students and employees dominate the number of respondents in this research. To test the research hypothesis, this research adopted the Structural Equation Model-Partial Least Square (SEM-PLS) technique using SmartPLS.

\section{RESULTS}

Evaluation in the measurement model can be seen from the relationship between constructs and indicators. There 


\section{Procedia Business and Financial Technology}

Proceedings of the 2nd International Conference on Business and M anagement of T echnology (ICO N BM T 2020) - Part 2

are 2 stages of measurement, namely evaluating conventional validity and discriminant validity. Where evaluating indicators of validity, extracted average variance, and construct reliability can be carried out by the conventional validity stage. The validity indicator has a statistical rank of more than 0.1 and a fact rating of more than 2.0, which allows adequate investigation. The results show that all indications of this idea can be very large, because they meet the conditions needed for the evaluation of validitymarkers.

It can be seen from Table 3 that all component values used in estimating the factors considered in this consideration are worth more than 0.5 and are the result of the significance test and then arrange with the measurement. Therefore, it can be seen that this indicator of thought has great legitimacy, because the collated picture is the relationship between this indicator and its evolution. Table 1 shows that all loading components are rated 2.0 or higher. So it is clear that we can say that every indicator in this idea has a significant justification. The legality estimate is built based on solid quality by assessing the quality of Cronbach's composite or alpha results. This shows that everything developed with this mindset can be said to be solid, with a combined rating above 0.70 and AVE rating above 0.50 .

In the next measurement model, it can be done in 2 stages on discriminant validity. Where the stage is to measure the value of cross loadings and compare the square of the correlation between constructs by adding the AVE value. There is a condition that must be specified in crossloading, that is, each indicator that measures the contract must have a higher correlation.the base value of AVE is 0.8905 higher than the maximum correlation value. So there is a load crossing output value that is in table 4 . It can be seen from table 4 that the study correlates higher in each of the existing constructs than the other constructs. So it can be concluded that the indicators in this study have a relatively good value of discriminant validity. Seen from the table 5 which has been shown that there is a maximum correlation value ofbrand awareness with other variables of 0.680 . Where the root value of AVE is 0.834 higher than the maximum correlation value. The maximum correlation value of the other variables in this study looks small from the AVE value. So it can be concluded that this study has good discriminant validity.

\section{DISCUSSIONS}

In this study successfully demonstrated that security perceptions have a positive and significant impact on online consumer satisfaction. This shows that the better security that is owned by an online store, the satisfaction of consumers can also increase the services or products offered by an online store. This research is also relevant to several experts. Therefore, online stores must pay close attention to aspects of security perceptions that must be highly maintained and improved so that our consumers get $124 / 180$ satisfaction and make repeated purchases of products or services offered at an online store.

This research does not prove that there is a positive and significant influence between privacy perception on satisfaction. Based on the results of research from several respondents, that privacy is not taken into account in customer satisfaction. But that does not mean that online stores do not need to protect customer privacy, online stores must maintain customer privacy, so that customers understand that personal data about themselves is guaranteed so that the online store has a good image in the eyes of customers.

On the other hand, this research also shows that brand awareness has a positive and significant influence on customer satisfaction. Consumers buy goods in brands they know now because they believe that the goods they buy are truly good quality goods so that a shopper can feel the satisfaction of an online store. Therefore, online storesmust have a high brand awareness so that customers can remember the brand that you make, in addition it must also have services or products that have good quality so that customers do not have doubts if they will buy the products or services offered. In this study successfully demonstrated that satisfaction has a positive effect on online consumer satisfaction. Trust has the result of evaluating the involvement of past exchanges.

Compliance appears if the client highlights and assesses their involvement in a previous exchange. Positive impressions and ratings from previous exchanges give buyers confidence to shop online. Wealthy customers not only trust customers, but repeat purchases. They will become customer reporters who will tell others about their extraordinary experience with the item.

In addition, this study successfully demonstrated that security perceptions have a positive and significant influence on online consumer confidence. This shows that trust can be realized if there are expectations in accordance with consumer needs. This shows that if the buyer feels that the online seller guarantees security on the exchange, consumers are sure to buy on the web. Other ideas are very useful to improve these observations. Therefore, online stores must maintain security perceptions with the trust of consumers who transact at the store. In this study successfully demonstrated that the perception of privacy has a positive and significant influence on online consumer confidence. This shows that the buyer feels safe for the services provided by the online store. Therefore, online stores will act in the same way as the wants and desires of consumers. In its extension, cognitive security can directly and certainly affect online shoppers. If the buyer feels that his personal property is safe, the customer can build trust and interact with online sellers. 


\section{Procedia Business and Financial Technology}

Proceedings of the 2nd International Conference on Business and M anagement of T echnology (ICO N BM T 2020) - Part 2

\section{CONCLUSIONS}

Based on the results of the study that has been explained the average supports all hypotheses raised inthis study. Then it can be concluded that brand awareness has a positive and significant influence on trust and satisfaction; security perceptions have a positive and significant influence on trust and satisfaction; satisfaction has a positive and significant influence on trust. In addition, this study also shows that satisfaction as a mediating variable in the relationship between security perceptions, privacy perceptions, and brand awareness with trust. But in this study privacy perceptions do not have a positive and not significant effect on satisfaction, which means that customer privacy does not significantly affect customer satisfaction.

\section{REFERENCES}

[1] R. Guo, W. Zhang, T. Wang, C. Bingxin, and L. Tao, "Timely or Considered? Brand Trust Repair Strategies and Mechanism after Greenwashing in China - from a Legitimacy Perspective," Ind. Mark. Manag., no. July 2017, pp. 1-11, 2017, doi: 10.1016/j.indmarman.2018.04.001.

[2] H. Chae, S. Kim, J. Lee, and K. Park, "Impact of Product Characteristics of Limited Edition Shoes on Perceived Value, Brand Trust, and Purchase Intention; Focused on the Scarcity Message Frequency," J. Bus. Res., no. November 2018, pp. 0-1, 2018, doi: 10.1016/j.jbusres.2019.11.040.

[3] S. Hussain, T. C. Melewar, C. Priporas, P. Foroudi, and C. Dennis, "Examining the Effects of Celebrity Trust on Advertising Credibility, Brand Credibility and Corporate Credibility," J. Bus. Res., vol. 109, no. November 2019, pp. 472-488, 2019, doi: 10.1016/j.jbusres.2019.11.079.
[4] A. Jafar, A. Y. A. Fianto, and S. P. Yosep, "Penciptaan Buku Ilustrasi Permainan Tradisional Sebagai Upaya Pelestarian Warisan Budaya Lokal," Art Nouv., vol. 3, no. 1, 2014.

[5] R. Santoso, R. A. Shintawati, and A. Y. A. Fianto, "Pengaruh Marketing Mix Produk Jasa terhadap Keputusan Berkunjung Wisata Bahari Jawa Timur," Kinerja, vol. 17, no. 1, pp. 69-79, 2020.

[6] E. Y. Ikawira and A. Y. A. Fianto, "Penciptaan Buku Ilustrasi Legenda Reog Sebagai Upaya Mengenalkan Budaya Lokal kepada Anak-Anak," Art Nouv., vol. 3, no. 1, 2014.

[7] R. D. Pinasti, A. Y. A. Fianto, and W. Hidayat, "Penciptaan Buku Komik Sebagai Upaya Pengenalan Permainan Tradisional Kepada Remaja," Art Nouv., vol. 4, no. 1, 2015.

[8] D. Y. Riyanto, N. Andriyanto, A. K. Riqqoh, and A.Y. A. Fianto, "A Conceptual Framework for Destination Branding in Jawa Timur, Indonesia," Maj. Ekon., vol. XXIV, no. 1411, pp. 149-157, 2019.

[9] A. Y. A. Fianto, "Satifaction As Intervening For The Antecedents Of Intention To Revisit: Marine Tourism Context In East Java," Relasi, vol. 16, no. 1, pp. 179- 207, 2020.

[10] R. Santoso, R. Shinta, and A. Y. A. Fianto, "Pengaruh Bauran Pemasaran Jasa terhadap Keputusan Berkunjung ke Wisata Bahari Jawa Timur," Manaj. dan Bisnis, vol. 4, pp. 1-14, 2019.

[11] A. Y. A. Fianto, "The Antecedents of Purchase Decision for Hijab Fashion Products," Manajemen, vol. 12, no. 1, pp. 154-165, 2020.

[12] R. Santoso, R. Shinta, and A. Y. A. Fianto, "Composing Marketing Mix for Better Destination Brand in Jawa Timur, Indonesia," Maj. Ekon., vol. XXIV, no. 1411, pp. 158-167, 2019. 